\title{
Motyw starości w wybranych utworach Franciszka Karpińskiego
}

Starość to ostatni z etapów ontogenezy człowieka. Jest on, obok dzieciństwa, młodości i wieku dojrzałego, waloryzowany w literaturze i kulturze w binarny sposób. Jako wynik przemijania ludzkiego życia, nieuchronnie prowadzi do śmierci i wiąże się z przypadłościami wieku - chorobami, nieporadnością, nieatrakcyjnością fizyczną i ułomnościami. Stąd negatywna ocena tej fazy życia. Z drugiej jednak strony w dyskursie kulturowym podkreślana i doceniana jest wartość doświadczenia życiowego i mądrości, które nabywa się z wiekiem. Temat ten doczekał się świetnie opracowanych syntez kulturoznawców francuskich ${ }^{1}$, natomiast w polskiej nauce o literaturze wciąż brakuje tego typu publikacji. Zbadanie oświeceniowej refleksji na temat jednego z etapów czasu antropologicznego (czasu człowieka ${ }^{2}$ ) stanowi cenny przyczynek do nadal mało opracowanego w piśmiennictwie naukowym zagadnienia, o tyle bowiem ważnego, że to poprzez czas człowiek poznaje siebie. Czas, obok ciała i przestrzeni, jest przecież paradygmatem natury i kultury, a człowiek jest warunkowany zarówno naturalnie (biologicznie), jak i kulturowo. $\mathrm{O}$ ile natura nie zmieniła w znaczący sposób długości biologicznych cyklów życia (choć zaobserwować można zjawisko jego wydłużenia, spowodowane osiągnięciami medycyny, dbałością o ciało, odpowiednią dietą czy aktywnością fizyczna), o tyle kulturowe podejście do starości wydaje się być we współczesnych latach odmienne od staropolskiego czy oświeceniowego spojrzenia na ten etap życia.

Celem niniejszej pracy jest analiza i interpretacja wybranych utworów Franciszka Karpińskiego pod kątem chronozoficznym, a nie poetyki tekstów. Zamierzenie to ma

\footnotetext{
* Ewelina Szymczak — studentka III roku doktoranckich studiów literaturoznawczych na Uniwersytecie Jana Kochanowskiego w Kielcach. Obecne interesuje się kategorią czasu antropologicznego w literaturze polskiego oświecenia, związana jest z Zakładem Badań Kulturowych Instytutu Filologii Polskiej. W pracy naukowej zajmuje się także kategoriami ciała i przestrzeni jako podstawowymi paradygmatami kultury. Zajmuje ją również kondycja współczesnego szkolnictwa. Opublikowała artykuł na temat kategorii zachwytu w twórczości Grażyny Drobek-Bukowskiej. Prowadzi szkolenia pedagogiczne w Niepublicznej Placówce Kształcenia Ustawicznego Tarbonus w Kielcach.

${ }^{1}$ Zob. G. Minois, Historia starości. Od antyku do renesansu, Warszawa 1995; J.-P. Bois, Historia starości. Od Montaigne'a do pierwszych emerytur, Warszawa 1996.
}

${ }^{2}$ Zob. A. Pawełczyńska, Czas człowieka, Wrocław 1986. 
doprowadzić do odpowiedzi na następujące pytania: jaki obraz ostatniego etapu ontogenezy człowieka został zaprezentowany w wybranych utworach, na ile ta wizja jest zgodna z oświeceniowym kulturowo-literackim modelem starości oraz czy poetyckie przemyślenia autora są nowatorskie i wnoszą coś do ogólnokulturowego dyskursu.

Czas od średniowiecza aż po barok nie był łaskawy dla starych ludzi. Z przyczyn oczywistych środowiska ubogie i wiejskie spychały problem starości na margines społecznego dyskursu. W bogatych rodzinach starzy ludzie mogli oczekiwać na śmierć w godnych warunkach, pomimo że nie uczestniczyli już aktywnie w życiu. „Po okrutnym XVI stuleciu wiek XVII traktował z ironią, oczerniał i odrzucał starość. Często mówi się, że XVIII wiek spojrzał na starych ludzi innym okiem”3. XVIII-wieczna dyskusja na temat podeszłego wieku początkowo opierała się na dwojakim wartościowaniu tego etapu życia, zgodnie z utrwalonym w kulturze modelem. Faza przejściowa między XVII a XVIII stuleciem to okres krytykowania starości z uwagi na nieprzydatność społeczną w wymiarze fizycznym i materialnym starych ludzi. Choć wskazywano się na mądrość i doświadczenie życiowe seniorów, to kwestia ich utrzymania nadal stanowiła problem ogólnoeuropejski. Warto zauważyć jednak, że powoli dokonywały się przemiany społeczne, niosące optymizm w relacjach starcy — społeczeństwo: osłabiła się augustyńska tradycja wycofywania się na starość z czynnego życia społecznego i nastąpiły powolne przemiany w relacjach rodzinnych, owocujące odkrywaniem instytucji babci i dziadka. To swoista rewizja starości. Jak zauważył Jean-Pierre Bois, „Role się odwróciły: teraz babki opowiadały wnukom o czarownicach”“. Odkryta na nowo mądrość starych ludzi, pociągająca za sobą konieczność szacunku i podziwu dla nestorów, prezentowana jest w pracach myślicieli i pisarzy XVIII wieku: Karola Ludwika Monteskiusza, François-Marie Aroueta (Woltera), Denisa Diderota czy Louis-Sébastiena Merciera.

Polskie oświecenie rozpatrywało starość zarówno z pozytywnej, jak i negatywnej strony. Co ciekawe, mało mówiło się o starych ludziach z nizin społecznych, z wiadomych powodów częstszymi przykładami byli arystokraci, wielmożni i szlachta. Biedny starzec (bądź staruszka) funkcjonowali jedynie w kpiarskich opowieściach lub byli figurą żebraka. Refleksja na temat starości znowu oscylowała wokół starczego wyglądu, chorób i niedogodności, a także mądrości, spokoju i swoistej majestatyczności. Literackie przykłady można by mnożyć, na potrzeby niniejszego opracowania wybrano kilka z nich.

$\mathrm{O}$ negatywnych aspektach starości w ujęciu fizjologicznym napomknął Ignacy Krasicki w bajce Syn i ojciec: „Każdy wiek ma goryczy, ma swoje przywary; Syn się męczył nad książką, stękał ojciec stary"5. Stękanie symbolizuje niedogodności starczego wieku, ból i niemoc ${ }^{6}$.

${ }^{3}$ J.-P. Bois, dz. cyt., s. 133.

${ }^{4}$ Tamże, s. 151.

${ }^{5}$ I. Krasicki, Bajki, oprac. J. Sokolski, Wrocław 1989, „Nasza Biblioteka”, s. 26.

${ }^{6}$ Podobnie problem ujął Franciszek Dionizy Kniaźnin, wpisując w utwór Życie moje topos czterech pór roku, jako symbolu poszczególnych etapów życia. Podkreślił także przemijający czas: 
Dysputę na temat fizjologii i seksualności starego podjął Krasicki w satyrze Życie dworskie. Wypowiadający się tu wieśniak zwrócił uwagę dworakowi, tytułowemu Joachimowi, na osłabnięcie żądz cielesnych w ostatniej fazie życia:

Joachimie! Już młodość porywcza uciekła

I wieku dojźrzałego już pora dociekła,

Ta pora, w której żądze słabieć zaczynają ${ }^{7}$.

Odmienne poglądy na starość wynikały z waloryzowania tego etapu życia z perspektywy doświadczenia oraz posiadanych umiejętności i były żywe w oświeceniowej Polsce. W satyrze Do króla Krasicki, co prawda, ironicznie wypowiadał się na temat opozycji starość - młodość, podkreślając starczą mądrość i praktykę życiową, jednak przesłanie utworu zgodne jest z poglądami większości ówczesnych ludzi, którzy młodego króla traktowali z pobłażaniem, a nawet wrogo, ponieważ nie wierzyli w jego umiejętności i posiadaną wiedzę. Utwór odwrócił sens popularnego w piśmiennictwie europejskim toposu puer senilis (puer senex) — chłopca, charakteryzującego się starczą mądrością:

\footnotetext{
Wszak siwizna zwyczajnie talenta posiada,

Wszak w zmarszczkach rozum mieszka, a gdzie broda siwa,

Tam wszelka doskonałość zwyczajnie przebywa.

Nie byłeś, prawda, winien temu, żeś niestary [... $]^{9}$.
}

Problem przemijania ludzkiego istnienia jest ponadczasowy i ogólnokulturowy. Starość była postrzegana z perspektywy ułomności i nieuchronnej śmierci. Widoczny lęk przed starością wynikał z braku przystosowania się do ograniczeń fizycznych zniedołężniałego ciała. Przeraża także rychłość śmierci. Na cztery aspekty lęku przed starością wskazywał Cyceron:

Bo też, kiedy się zastanawiam nad starością, cztery widzę przyczyny, dla których starość zwykliśmy uważać za nieszczęśliwy okres życia: oddala nas ona od życia czynnego, osłabia siły fizyczne, pozbawia nas wszystkich zmysłowych przyjemności, bliską jest śmierci ${ }^{10}$.

Także paremiologia staropolska i oświeceniowa wyraźnie wskazują na pejoratywne odbieranie starości. Aforyzmy i przysłowia: „Biedna starości! Nosząc cię, bolą kości;

Mijają płonnym dni moje przelotem,

W nudnych zgryzotach i lichej bidzie

A gdy czas letni tym zmyka obrotem,

Nie inna pewnie i jesień przydzie.

Zob. F. D. Kniaźnin, Erotyki, t. 2, Warszawa 1779, s. 192-193.

${ }^{7}$ I. Krasicki, Satyry i listy, wyd. 3 popr., oprac. Z. Goliński, Wrocław 1999, BN I 169, s. 61-67.

${ }^{8}$ E. Curtius, Literatura europejska i łacińskie średniowiecze, Kraków 2005, s. 107-114.

${ }^{9}$ I. Krasicki, Satyry i listy, s. 3-10.

${ }^{10}$ M. T. Cicero, Katon Starszy o starości, [w:] Pochwata starości. Cyceron. Katon Starszy o starości. Plutarch. Czy stary człowiek powinien zajmować się polityką?, tłum. Z. Cierniakowa, A. Twardecki, Warszawa 1996, s. 35. 
Sama starość stoi za chorobę; Starość nie sama przychodzi: kupę z sobą chorób wodzi; Starość w grób zamyka"11, są potwierdzeniem myśli Cycerona — ostatni etap czasu człowieczego napawa bojaźnią i trwogą.

Franciszek Karpiński, zgodnie ze zdaniem Heraklita z Efezu, że wszystko płynie i nic nie pozostaje takie samo, kilkakrotnie zaznaczył ulotność życia. Paradoksalnie w wierszu Zabawa na ustroniu. Myśl z angielskiego Arystypa zaprezentował stoicką postawę wobec przemijalności istnienia, pomimo odwołań do hedonistycznej filozofii Arystypa z Cyreny. Podkreślił pęd mijającego życia i skontrastował go z egzystowaniem „na łonie słodkiej spokojności” ${ }^{12}$.

Poecie przyświecała także maksyma Owidiusza, głosząca, że „czas upływa, a my starzejemy się wraz z cicho upływającymi latami (Tempora labuntur tacitisque senescimus annis)”'13. Ważna jest jednak roztropność i rozwaga, bo choć „mienią się lata, noc za dniem żenie" 14 , człowiek powinien obrać sobie cel, jaki będzie mu przyświecał przez całe życie. Dla podmiotu lirycznego wiersza Stateczność jest nim miłość. Osoba mówiąca nawołuje do zaprzestania narzekania, ponieważ „próżno z mocnymi walczyć niebiosy i na uparte narzekać losy!" ${ }^{15}$. Znamienne jest odwołanie do słów Biblii, gdzie losy człowieka pokłada się w rękach Pana ${ }^{16}$.

W utworze $O$ uspokojeniu z cnoty poeta powielił motyw życia jako mgnienia i podkreślił krótkość istnienia ziemskiego, które o tyle jest coś warte, o ile nie marnuje się danego czasu:

\footnotetext{
My bardzo krótko żyjemy

i nic o jutrze nie wiemy

Za cóż ten kwasić czas mamy?

Nieba nie na to go dały ${ }^{17}$.
}

Podobnie rzecz ma się w tłumaczonym przez poetę Psalmie $38^{18}$ :

Pod liczbą każdy dzień się ludziom daje,

Niech wiem, czego mi jeszcze nie dostaje?

Ty, mocny Boże, dni moich mierniczym,

I moja istność przed Tobą jest niczym.

\footnotetext{
${ }^{11}$ Zob. hasło: Starość, S. Adalberg, Ksiega przystów, przypowieści i wyrażeń przystowiowych polskich, Warszawa 1889-94, s. 575-576.

${ }^{12}$ F. Karpiński, Wiersze zebrane, Część 1, wyd. T. Chachulski, Warszawa 2005, s. 64.

${ }^{13}$ P. Ovidius Naso, Fasti: Kalendarz poetycki, Kraków 2008, 6, 771.

${ }^{14}$ Tamże, s. 141-142.

${ }^{15}$ Tamże, s. 141.

${ }^{16}$ Ps 31,15 .

${ }^{17}$ F. Karpiński, Wiersze zebrane, s. 111-112.

${ }^{18}$ Zob. Ps. 39 (38), 5-12.
} 
Człowiek żyjący swoją próżność słodzi,

A sam jako cień znikomy przechodzi.

Próżno się troszcze o skarbu zebranie,

Bo nie wie, komu po nim się zostanie ${ }^{19}$.

Marność człowieka skontrastowana jest z wielkością Boga. Topos wanitatywny podkreślił ulotność życia. Człowiek jest niczym więcej, jak cieniem, trawą, pyłem — tempo upływającego czasu jest zatrważające. Nadzieją ludzką jest Pan Bóg. To On wyznacza miarę życia. Poddanie się woli Boga jest wszystkim, co człowiek może uczynić. Wobec śmierci przestają mieć znaczenie zgromadzone dobra materialne, one pozostaną na ziemi. Podmiot mówiący wyraził powątpiewanie w sens materialistycznego podejścia do życia, bowiem nie wiadomo, kto skorzysta z majątku i jak go spożytkuje. Taką samą postawę zaprezentował poeta w wierszu Irus bliski śmierci, gdzie tytułowy Irus — biedak, żebrak, stojący od starożytności w opozycji do postaci Krezusa — jawnie skrytykował postawę materialistyczną, bowiem w obliczu śmierci zarówno młody, jak i stary, bogaty, czy też biedny, stali się równi sobie. Pewne jest tylko to, że los odbierze to, co dał, a życie ludzkie kiedyś się skończy.

Łacińska sentencja tempora mutantur et nos mutamur in illis patronuje utworowi Ja już nie ten. Powodem do narzekania dla podmiotu lirycznego stał się nieubłagany upływ czasu. Bohater nie był już statecznym człowiekiem, który pokornie przyjmowałby wyroki boskie. Był zasmucony brakiem powodzenia u młodych kobiet i wyrażał swój żal za straconą młodością, co za tym idzie siłami witalnymi oraz młodzieńczym wyglądem. Zauważał bezsensowność swych starań o uwagę panien. Przestrzegał także przed marnowaniem pięknych lat, namawiał do używania życia:

Lata moje ustąpiły,

Nie wiodą już o mnie spory,

Jak się dziewczęta kłóciły [...]

Dzisiaj, podstarzały,

Próżno dla kochanki

I śpiewam dzień cały

I przynoszę wianki.

Schylam się już do wieczora;

Już ja nie ten, co był wczora!

Przedtym, gdy mi młodość służy,

Każda mię ujmować

chciała $[\ldots]$

Dziś ledwie wyproszę,

By mi kwiatek dały

I łudząc się, noszę

Ten znak dawnej chwały.

Schylam się już do wieczora;

Już ja nie ten, com był wczora.

${ }^{19}$ F. Karpiński, Poezje wybrane, wyd. 2 zmien., oprac. T. Chachulski, Wrocław 1997, BN I 89, s. 127-129. 
Rzeka w górę nie popłynie,

I nie wrócą się me lata;

Wiek mu cały marnie zginie,

Kto z młodu nie użył świata [...]

Dziś ci pole służy,

Jutro będzie słota.

Schylam się już do wieczora;

Już ja nie ten, com był wczora ${ }^{20}$.

Takie widzenie świata nie było niczym nowym. Bohater liryczny stał się z gruntu anakreontowski ${ }^{21}$, skarżył się na niemożność powrotu do młodych lat. Podstarzały Anakreont użalał się przede wszystkim na fizyczne ograniczenia i przywary starości: zmiany w wyglądzie, utratę sił witalnych i rychłe widmo śmierci. Bohater Karpińskiego, obok zmian fizjonomicznych, zauważył jeszcze inne problemy starości: wyalienowanie ze środowiska, bycie pośmiewiskiem, a w konsekwencji przejmującą samotność. Ten etap egzystencji ludzkiej wpisał w znany topos życia jako doby (dnia i nocy). Schylanie się do wieczora stało się symbolem starości i zapowiedzią śmierci ${ }^{22}$. Silna polaryzacja

${ }^{20}$ Tamże, s. 97-98.

21 Osiwiały zwiędłe skronie,

Ubieliła głowę zima,

Przeminęła rzeźwa młodość

I nie służą stare zęby...

Nie na długo starczy życia,

Coraz bliżej kres radości...

Oto łzy rzęsiste leję,

Bo mi straszny mrok Tartaru.

W Aidowej źle czeluści,

Niewesoło zejść pod ziemię;

Skoroś raz w te kraje zstąpił,

Nie powrócisz, człecze, więcej.

Zob. Antologia liryki greckiej, oprac. W. Steffen, przekł. zbior., Wrocław 1955, BN II 92, s. 133-134.

${ }^{22} \mathrm{~W}$ podobny sposób na temat przemijania życia wyraził się Kniaźnin, który, nawiązując w wierszu Jesień do toposu czterech pór roku, podkreślił rychłe przemijanie dzieciństwa (wiosny) i młodości (lata) oraz urody, podniet i uciech życia, ponieważ taka jest naturalna kolej rzeczy, por. F. D. Kniaźnin, dz. cyt., s. 153-154.

Podobnym trybem ludzkie podniety

Błysną, połechcą i giną.

$\mathrm{Z}$ wiekiem uroda i blask kobiety

Jak wody potoczne płyną.

Wszystko, co widzim, na świecie mija,

Wszystko się rychło starzeje.

Dzień za dniem leci, a czas wywija

Odmienne coraz koleje [...]

Kostunio moja! pięknaś, bo młoda;

Powabnaś, boś kwiatek świeży.

Lecz w to nie ufaj: blask i uroda

Jak wiosna z latem ubieży. 
młodości i starości sprawiła, że wiersz jest przejmującym rozliczeniem osoby mówiącej z dotychczasowym życiem i ze starczymi złudzeniami.

Karpiński nie pominął w swych utworach tematyki poszukiwania miłości na starość. Mając młody wiek za sobą, zwrócił się w wierszu Do mojej przyszłej do wymarzonej przyszłej partnerki. Podkreślił, że nie chciał młodej trzpiotki, ale pragnął związu z dojrzałą, radzącą sobie z każdym problemem kobietą:

\footnotetext{
Ty, co mym będziesz przywarom ulegać

I późny ogień miłości zażegać [...]

Nie chcę cię młodym ozdobionej wiekiem,

Ani przyprawnych jagód róży z mlekiem:

Zima nadchodzi, minąłem się z latem,

$\mathrm{Na}$ cóż na mrozy narażać się z kwiatem?

Z którą się wiekiem różniemy niewiele,

Która ma cnotę i rozum w podzielę $[\ldots]^{23}$
}

Co ważne, Karpiński rozumiał bezsensowność związku starego mężczyzny i młodej kobiety, wiedział, że w takiej relacji kobieta nie będzie szczęśliwa. Starość, zgodnie z toposem czterech pór roku pojmowana jako zima, spowoduje przemarznięcie młodego kwiatu. Pogodzenie się z własną starością mogło wynikać z dwóch czynników. Pierwszym z nich byłaby dojrzałość człowieka, świadomego praw przemijania. Co prawdopodobne, taka postawa mogłaby być efektem reakcji młodych kobiet, ironicznie traktujących zakochanego starca.

Z kolei w wierszu Trzeba się kochać Karpiński podkreślił obowiązek korzystania z życia za młodych lat. Idąc znów tropem Anakreonta, podtrzymywał, że dopóki rzeźwiejsze lata nie miną, trzeba wykorzystywać sytuacje, jakie dawało życie. Warto przede wszystkim oddać się miłości, która jest w egzystencji ,jedyną pociechą”. W ten sposób nawiązał do toposu wyśmiewanego zakochanego starca czy starej kobiety ${ }^{24}$, którym nie przystoi przecież uganianie się za młodymi dziewczętami lub mężczyznami. Każdy etap życia rządzi się wszakże swoimi prawami. Starość nie jest bynajmniej dobrym czasem na zakochanie, tym bardziej na związek z młodą kobietą czy chłopcem.

Ten sam problem ukazał Karpiński w Pieśni do trzech panien. Wiersz nosi znamiona autobiograficzne, przypuszcza się, że powstał w „pierwszym dwudziestoleciu XIX wieku". Twórca był więc wtedy w podeszłym wieku, mógł mieć od sześćdziesięciu kilku do osiemdziesięciu lat. Zadedykowany został trzem młodym kobietom z otoczenia Karpińskiego ${ }^{25}$. Poeta zdawał sobie sprawę z ograniczeń, jakie niesie jego wiek. Dostrzegł, że nie był już dla dziewcząt atrakcyjny. Charakter jego wypowiedzi nie jest jednak lamentacyjny. Ze spokojem i lekką nutą rozczarowania sobą i swoimi możliwościami snuł refleksję na temat własnej starości:

\footnotetext{
${ }^{23}$ F. Karpiński, Pisma wierszem i proza, Warszawa 1896, „Biblioteka Najcelniejszych Utworów Literatury Europejskiej", s. 146.

${ }^{24}$ J.-P. Bois, $d z$. cyt., s. 58-59.

${ }^{25}$ F. Karpiński, Poezje wybrane..., s. 187-188.
} 
A ja stary, a wy młode.

Jakąż z wami mam zabawę?

Trudno zgodzić $\mathrm{z}$ ogniem wodę.

Stary z młodą przegra sprawę.

W smutku, chcąc rozrywki w świecie,

Czynię wam z serca ofiary.

Jakże wy to przyjmujecie?

Biedny! Zapomniał, że stary.

W najpierwszym tej pieśni słowie

Wszystkie trzy jesteście w szyku.

Wy mi w sercu, wy mi w głowie,

Ja wam tylko na języku ${ }^{26}$.

W zacytowanym utworze poeta także zaprzeczył toposowi zakochanego lubieżnika ${ }^{27}$. Widział wyraźnie, że panny odnosiły się do jego zapędów z politowaniem i dobrodusznością. Dziewczęta nie były w stanie wykrzesać żadnych gorących uczuć względem Karpińskiego, ponieważ nie był on już dla nich atrakcyjnym mężczyzną. Pomimo tego, że poeta myślał ciepło o pannach, żywił do nich pozytywne uczucia, jednak wiedział, że młode kobiety tylko wyśmieją jego zabiegi. Poparł swą refleksję porównaniem młodości do buchającego ognia i starości do wody, które to żywioły z natury rzeczy się wykluczają. Ognista krew młodych kobiet nigdy wodą nie będzie, starość ostudziłaby ich ewentualne zapały.

Karpiński poruszył też problem przyjaźni między starym a młodym w wierszu Do Antoniego Kornitowicza misjonarza, nauczyciela wymowy i poezji w szkole tyskowskiej. Podmiot liryczny, utożsamiany z przesłanek biograficznych z osobą autora, podkreślił wagę cnoty i wiedzy u młodego człowieka, które czyniły go godnym zaufania i przyjaźni starych ludzi: „Jesteś lat młodych, to z większą twą chwałą, / Że nam się, starym, przypodobać umiesz" ${ }^{28}$. Wnioskować można, że starsze osoby stawiały młodym przyjaciołom większe wymagania, ale kiedy pozytywnie oceniały młodego człowieka, potrafiły go docenić. Tym samym Karpiński wskazał na mądrość i doświadczenie starca, który, przeżywszy już wiele, był w stanie dokonać wyważonego osądu.

Sentymentalny Karpiński skupił się w swych utworach na przeżyciach starego człowieka, jego wyglądzie, przywarach i ograniczeniach. Mało mówił o mądrości życiowej, rzadko podnosił też motyw starego mędrca. Bardziej niż mądrość i doświadczenie, przemawiały do niego uczucia zakochania, podniecenia i miłości. Starość te doznania wyklucza - wygląd nie pozwala już mieszać w sercach, rodzą się swoiste ograniczenia

\footnotetext{
${ }^{26}$ Tamże.

${ }^{27} \mathrm{~W}$ topos lubieżnego starca wpisała się fraszka Jana Kochanowskiego Do dziewki. Podmiot mówiący, podstarzały adorator, chciał zainteresować swą osobą młodą kobietę. Wskazał na nieograniczone możliwości w alkowie i przypływ sił witalnych pomimo siwej głowy, zob. J. Kochanowski, Fraszki, wyd. 2 zmien., oprac. J. Pelc, Wrocław 1991, BN I 163, s. 157.
}

${ }^{28}$ F. Karpiński, Pisma ..., s. 213. 
wieku, człowiek nie jest atrakcyjny, postawny, silny i sprawny. Stąd krytyka ostatniego etapu życia człowieka. Starość to dla poety czas zakończenia miłości, a zarazem początek smutnego i samotnego życia. Cóż mu po mądrości, gdy nie ma przy sobie ukochanych Justyn i Rozyn? Jego utwory o tematyce przemijania i starości przepełnione są rozczarowaniem samym sobą — nie był w stanie przykuć uwagi kobiet, wszystkie odwracały się od niego, bo nie był piękny i młody, i patrzyły na jego umizgi z rozbawieniem i pobłażaniem. Jedyne, co potrafiły względem niego wykrzesać, to politowanie. Karpińskiemu pozostała więc smutna refleksja.

Choć myśl chronozoficzna była u Franciszka Karpińskiego bogata, to nie była nowatorska. Poeta opisał zarówno temat upływu czasu, jak i wypowiadał się o starości, odwołując się do znanych toposów i motywów. Nie wnosił tym samym nic nowego do dyskusji kulturowej na temat starości. W jego wierszach brak aspektu pozytywnego ostatniego etapu życia. Zgodnie z polskim oświeceniowym modelem, omawiana poezja wpisuje się w nurt krytyki starości, choć nie jest w krytyce tak radykalna, jak wskazywałaby na to sytuacja społeczno-polityczna.

Nieprzychylność w stosunku do starości w polskich realiach oświeceniowych i późniejszych wiązała się z wydarzeniami historycznymi: w czasie zawieruch politycznych to starzy ludzie zostawali w domach, nie mogąc bronić kraju. Nie wpisywali się tym samym w mit martyrologiczny. Nie mieli też często sił, by pomagać pozostałym w gospodarstwach kobietom — to także sprzyjało pejoratywnemu odbiorowi starości. Należy zauważyć, że pomimo przemian kulturowych w oświeceniowej Europie, w Polsce niewiele się zmieniło.

Karpiński sam dożył późnej starości (przeżył 84 lata). Wypowiedzi poety na temat tego okresu w życiu są więc poparte osobistym doświadczeniem w racjonalnym duchu epoki. Starość nie była dla niego zbyt miłym czasem, uprzyjemniał go jednak grą na gitarze, nucąc słowa jednego z ulubionych wierszy Ja już nie ten $n^{29}$. Można więc uważać niniejszy utwór za osobiste wyznanie Karpińskiego. Utwór jest o tyle wiarygodny, że poparty faktycznym pamiętnikiem autora, w którym starość także ukazana została w nieprzychylny sposób. Wspomnienia są co prawda kreowane według sentymentalnego wzorca, jednak taki sposób wypowiedzi tylko intensyfikuje negatywne stanowisko wobec ostatniego etapu życia. W momencie ich spisywania Karpiński miał 81 lat, podjął się zadania, „spodziewając się umrzeć niezabawem”30. Wiadomo z pamiętnika, że w ostatnich dwudziestu latach życia borykał się z depresją, „uważając siebie coraz bardziej cierpiącym i doświadczającym od lat dwudziestu czarnej melancholii, która się coraz bardziej powiększa" ${ }^{31}$. Wspominał też o swoich ograniczeniach, jakie ze starości wynikały: „Ale choć go wprawdzie kocham [starostę Siehenia, przyjaciela Karpińskiego — dop. E. Sz.], bywać u niego nie mogę dla słabości zdrowia, w której ledwie mogę po pokoju przechodzić się, więcej dnia na leżeniu i trochę siedzeniu przepędza-

\footnotetext{
${ }^{29}$ Zob. F. Karpiński, Poezje zebrane, s. 97, oraz F. Karpiński, Wiersze zebrane, s. 319-320.

${ }^{30}$ F. Karpiński, Historia mego wieku i ludzi, z którymi żytem, oprac. R. Sobol, Warszawa 1987, s. 205.

31 Tamże.
} 
jąc”32. Pamiętnik jest także okazją do pięknego pożegnania z rodziną: „Piszę ja ten mój rękopism w roku 1822, w roku zaś ośmdziesiątym pierwszym życia mojego. I będąc tak już na siłach słaby, żegnam się z wami najpierwej, krewni moi [...]"33. Rozpatrywana z perspektywy chorób, niemocy i depresji, starość nie mogła więc być przez autora waloryzowana inaczej niż negatywnie. Pomimo że refleksja Karpińskiego nie dawała nowego obrazu starości i nie powodowała odmiennego jej odczytania, ważne, że wynikała z jego własnych przeżyć i doznań. Twórczość dotycząca starości jest więc cenna dla badań nad czasem antropologicznym z powodu osobistego doświadczenia poety, które jest zarazem głosem pokolenia.

Ewelina Szymczak

The Motif of Old Age in Selected Works by Franciszek Karpiński

\section{Summary}

The present article focuses on the aspect of old age in Franciszek Karpiński's works. The main object of the article is to analyse an Enlightenment reflection on the category of anthropological time in selected poems and a sentimental diary of Karpiński. Rich, however not innovative, chronosophical reflection of the writer, complies with the Enlightenment critique model of old age understood as time of physical constraints and lack of attraction resulted from changes influenced on a human body.

Słowa kluczowe: chronozofia, czas antropologiczny, Franciszek Karpiński, oświecenie polskie, starość

Keywords: chronosophy, anthropological time, Franciszerk Karpiński, Polish Enlightenment, old age

\footnotetext{
32 Tamże, s. 207.

${ }^{33}$ Tamże.
} 